\title{
MECHANICAL PERFORMANCE OF BITUMINOUS CONCRETE INCORPORATING STEEL SLAG WITH NATURAL AGGREGATE
}

Satish Pandey, Scientist*, CSIR-Central Road Research Institute, Mathura Road, New Delhi 110025, India,

Dr. P.K.Jain, Chief Scientist, CSIR-Central Road Research Institute, Mathura Road, New Delhi 110025, India,

*Corresponding mail ID: satishpandey.crri@nic.in

doi: 10.2478/ijpeat-2013-0003

\begin{abstract}
India has world's second largest road network in terms of length with a total road length of 4.24 million $\mathrm{km}$. Hot mix bituminous pavement contributes around 50\% road length to this vast road network. Large scale highway construction in India, emanating from rapid development, has caused massive depletion of scarce natural aggregate. This paper addresses this problem by investigating the influences of the utilization of steel slag as a coarse aggregate on the properties of hot mix bituminous concrete. Physical characteristics of bituminous mix ingredients i.e natural aggregate, steel slag aggregate and bituminous binder were determined to find out their compliance with Ministry of Road Transport and Highway Specification for Road and Bridge Works in India. Mechanical characteristics of bituminous mixes i.e Unmodified (having natural aggregate) and Modified (having steel slag as coarse aggregate) were determined using Marshall Method of mix design.

Unmodified and Modified mixes were subjected to an array of performance tests to check out the suitability of steel slag aggregates for the preparation of high performance bituminous concrete mix. The performance tests includes, retained Marshall Stability, indirect tensile strength, static creep test, wheel-tracking test and resilient modulus test. The laboratory study confirmed the improvement in various mechanical properties of steel slag modified mixes besides reduction in temperature and moisture susceptibility.
\end{abstract}

Key Words: Steel Slag Aggregate, Natural aggregate, Bituminous Mix, Bituminous Pavement.

\section{INTRODUCTION}

The development of the highway construction industry in India under the aegis of National Highway Development Program (NHDP), has posed great demand of natural aggregates for road construction. As the resources for naturally occurring aggregates diminished at an ever increasing rate, road industries are keen to utilize recycled and waste materials in road construction in harmony with sustainable development. Steel slag, a waste product from the steel making industry, is one of the recycled materials reported to exhibit great potential to replace naturally occurring aggregates in bituminous mixes. 
Metallurgical waste particularly steel slag, generated in India is mostly collected by the waste producers themselves and partly by the companies doing separate collection of waste as their primary activity. The generated steel slag waste is partly recovered and returned to the production process (reuse) and part of the waste is sometimes used by other industries as secondary raw material (recycling), whereas the largest part still ends on often non-regulated landfills as industrial waste in adjoining areas. Disposal of steel slag as landfills are particularly hazardous for the environment.

Steel slag, a by-product from the steel making process had been reported to exhibit great potential as a replacement for natural aggregates in road construction (Bagampadde U., et al,1999; Juan M. M., et al,2005; Hunt L., et al,2000). Besides having better mechanical properties than natural aggregates, steel-slag aggregates have been reported to retain heat considerably longer than natural aggregates (Hamzah O. M., et al,2008). The heat retention characteristics of steel-slag aggregates can be advantageous for HMA construction, as less gas (energy) is used during the execution of asphaltic concrete works. Mladen F.,et.al. 2010, explored the possible utilization of Basic Oxygen Furnace (BOF) slag in asphalt concrete. Their study confirmed that the asphalt produced with BOF slag exhibit good resistance to permanent deformation, high stability with good flow properties and high stiffness modulus.

India is the $4^{\text {th }}$ largest steel producer in the world with total steel production of $72 \mathrm{MT}$ per annum. Steel slag generated in steel manufacturing industries obtained from Basic Oxygen Furnace (BOF) and Electric Arc Furnace (EAF), is another waste from iron and steel industries in India. It is non-hydraulic and crystalline in nature and rich in $\mathrm{Fe}_{2} \mathrm{O}_{3}$ content (20-30 percent). The limited use of steel slag in Indian steel plants (less than $30 \%$, mainly used in sinter plant as lime substitute) and use of recovered metallic's in steel making remains a matter of concern for steel industries (CPCB Report,2006-07). In contrast in developed countries, the use of steel slag as construction material ensuring 100\% utilization. Harsco India Private Limited which deals in Slag Co Products approached CSIR-CRRI for laboratory evaluation of processed steel slag aggregates to find out its suitability in road construction. Steel slag generated in Electric Arc Furnace (EAF) is considered for laboratory evaluation.

\section{OBJECTIVES}

Most projects in India involving steel slag aggregates as construction material are using this recycled aggregate in lower quality applications such as road bases rather than wearing course. The aim of this research is to study the performance of steel slag as road pavement aggregates compared to the conventional use of silicious aggregates for the same purpose. The detailed objectives are outlined below:

(1) To assess the physical and mechanical characteristics of steel slag aggregate to find out its suitability in high performance bituminous concrete mix. 
(2) To assess the performance of bituminous concrete mix prepared using steel slag aggregate with siliceous natural aggregate and bituminous concrete mix having 100 $\%$ natural siliceous aggregates.

(3) To evaluate the effect of moisture and temperature on the performance of mixes incorporating steel slag.

(4) To compare the performance of Steel slag modified mix and Unmodified mix having natural aggregates.

\section{MATERIALS AND METHODS}

The study is divided into three main phases. The first is related to the physicochemical characterization of the steel slag aggregate, natural aggregate and bitumen. The second phase deals with bitumen mix designs which were two mixes; One with an integrated slag-natural aggregate matrix (Steel slag modified mix) and one with only natural aggregates (Unmodified Mix) used as a control mix. Third phase covers the various performance tests carried out to assess mechanical characteristics of steel slag modified and unmodified mix.

\section{Material Used}

The processed steel slag aggregates used in the study was supplied by HARSCO India Private Limited. Steel Slag was generated as a melt at about $1650^{\circ} \mathrm{C}$ during steelmaking from hot metal, direct reduced iron or scrap. It consisted of oxidized co-elements of the hot metal and other metallic charges which reacted with the added limestone and dolomite. Depending on the process technology, one could distinguish Basic Oxygen Furnace (BOF) and Electric Arc Furnace (EAF) slag. The chemical composition of EAF steel slag used in the study is given in Table 1.

Calcium oxide $(\mathrm{CaO})$, iron oxide $(\mathrm{FeO})$ and silica $\left(\mathrm{SiO}_{2}\right)$ are the three major chemical constituents of both EAF and BOF slags. Due to the presence of unstable phases in its mineralogy, steel slag can show volumetric instability, caused mainly by the presence of free $\mathrm{CaO}$. In the presence of water, free lime hydrates and forms portlandite $(\mathrm{Ca}(\mathrm{OH}) 2)$. Portlandite has a lower density than $\mathrm{CaO}$ and hence, hydration of free $\mathrm{CaO}$ results in volume increase (Irem Z. Y. et al, 2011).

In order to reduce the expansibility of steel slag aggregate, several aging methods can be used like air aging, hotwater aging and steam aging; under first method steel slag is left out in the open for 1 month for weathering through air (air aging), in the second method i.e hot water aging steel slag is immersed in hot water at $80 \pm 3{ }^{\circ} \mathrm{C}$ temperature for 1 day or 3 days and the last method exposes steel slag aggregate to steam at $100^{\circ} \mathrm{C}$ for over 3 days (steam aging) (Han Y. M., et al, 2002) . 
Table 1: Chemical Composition of Steel Slag

\begin{tabular}{|c|ll|c|}
\hline S.No. & \multicolumn{2}{|c|}{ Type of Oxide } & Oxide Content \% \\
\hline 1$)$ & Calcium & $-\mathrm{CaO}$ & 42.0 \\
\hline 2$)$ & Iron & $-\mathrm{FeO}$ & 17.7 \\
\hline 3$)$ & Silica & $-\mathrm{SiO}_{2}$ & 17.2 \\
\hline 4$)$ & Magnesium & $-\mathrm{MgO}$ & 7.2 \\
\hline 5$)$ & Aluminium & $-\mathrm{Al}_{2} \mathrm{O}_{3}$ & 7.1 \\
\hline 6$)$ & Manganese & $-\mathrm{MnO}_{2}$ & 4.3 \\
\hline 7$)$ & Phosphorous & $-\mathrm{P}_{2} \mathrm{O}_{5}$ & $<1$ \\
\hline 8$)$ & Sulphur & $-\mathrm{SO}_{3}$ & $<1$ \\
\hline 9$)$ & Potassium & $-\mathrm{K}_{2} \mathrm{O}$ & $<1$ \\
\hline 10$)$ & Sodium & $-\mathrm{Na}_{2} \mathrm{O}$ & $<1$ \\
\hline 11$)$ & Chromium & $-\mathrm{Cr}_{2} \mathrm{O}_{3}$ & $<1$ \\
\hline
\end{tabular}

Physico-Mechanical properties of natural aggregates and steel slag aggregates were determined through laboratory tests to assess the suitability of aggregates in bituminous mixes. Table 2 reports the physical and mechanical properties of aggregates as well as specific test protocol adopted.

For the preparation of bituminous mix, Viscosity Graded bitumen binder (VG 30) was considered. To find out the suitability of bitumen binder for preparation of bituminous mix, various physical properties of bitumen were determined as per relevant Indian standard specifications. Properties of bitumen binder obtained from laboratory testing are reported in Table 3. 
Table 2: Physical-Mechanical Properties of Aggregates

\begin{tabular}{|c|c|c|c|c|}
\hline \multirow[t]{2}{*}{ Properties Tested } & \multicolumn{2}{|c|}{ Test Results } & \multirow{2}{*}{$\begin{array}{c}\text { Specified } \\
\text { Limits in } \\
\text { MoRTH } \\
\text { Specification }\end{array}$} & \multirow{2}{*}{$\begin{array}{c}\text { Testing } \\
\text { Specifications }\end{array}$} \\
\hline & $\begin{array}{c}\text { Natural } \\
\text { Aggregates }\end{array}$ & $\begin{array}{c}\text { Steel Slag } \\
\text { Aggregates }\end{array}$ & & \\
\hline $\begin{array}{l}\text { Los Angles Abrasion } \\
\text { Value }\end{array}$ & $14.23 \%$ & $12.06 \%$ & $30 \% \max$ & IS 2386 (Part-V) \\
\hline Aggregate Impact Value & $21.64 \%$ & $16.67 \%$ & $27 \% \max$ & IS 2386 (Part IV) \\
\hline $\begin{array}{l}\text { Soundness } \\
\text { i) Sodium Sulphate } \\
\text { ii) Magnesium Sulphate }\end{array}$ & $\begin{array}{l}5.60 \% \\
4.80 \%\end{array}$ & $\begin{array}{l}4.30 \% \\
5.10 \%\end{array}$ & $\begin{array}{l}\text { Max.12\% } \\
\operatorname{Max} 18 \%\end{array}$ & IS 2386 (Part-V) \\
\hline $\begin{array}{l}\text { Combined Elongation } \\
\text { and Flakiness Index }\end{array}$ & $25.20 \%$ & $8.95 \%$ & $30 \% \max$ & IS 2386 (Part I) \\
\hline Water Absorption Value & $0.70 \%$ & $0.80 \%$ & $2 \% \max$ & IS 2386 (Part III) \\
\hline Specific Gravity & 2.75 & 3.06 & $2.5-3.0$ & IS 2386 (Part II) \\
\hline $\begin{array}{c}\text { Stripping } \\
\text { (Retained Coating \%) }\end{array}$ & 99.00 & 99.50 & $\begin{array}{c}\text { Minimum } \\
\text { retained coating } \\
95 \%\end{array}$ & IS 6241 \\
\hline
\end{tabular}

Table 3: Bitumen Characterization

\begin{tabular}{|l|l|c|c|}
\hline \multicolumn{1}{|c|}{ Physical Properties } & \multicolumn{1}{|c|}{$\begin{array}{c}\text { BIS Test } \\
\text { Methods }\end{array}$} & $\begin{array}{c}\text { Type of } \\
\text { Binder } \\
\text { VG-30 }\end{array}$ & $\begin{array}{c}\text { Requirements } \\
\text { of IS 73:2006 } \\
\text { for VG 30 }\end{array}$ \\
\hline Penetration $25^{\circ} \mathrm{C}, 100 \mathrm{~g}, 5 \mathrm{sec}, 0.1 \mathrm{~mm}$ & IS $1203-1978$ & 62 & $50-70$ \\
\hline Softening point $(\mathrm{R} \mathrm{\&} \mathrm{B}),{ }^{\circ} \mathrm{C}$ & IS1205-1978 & 49 & Min. 47 \\
\hline Ductility, cm at $27^{\circ} \mathrm{C}(5 \mathrm{~cm} /$ min pull) & IS $1208-1978$ & 78 & Min.75 \\
\hline Specific gravity at $27^{\circ} \mathrm{C}$ & IS $1202-1978$ & 1.01 & Min. 0.99 \\
\hline Absolute Viscosity, at $60^{\circ} \mathrm{C}$, (Poise) & IS1206 (Part 2) & 2570 & $2400-3200$ \\
\hline
\end{tabular}

\section{Mix Design}

Two fractions of natural aggregates and processed steel slag aggregates i.e $0-10 \mathrm{~mm}$ and 10-20mm, Stone Dust and hydrated lime are combined together to obtain desired aggregate blend meeting the gradation requirements of MoRTH specification for Road and Bridge work for bituminous concrete (BC). Stone dust collected from aggregate crusher is used as fine aggregate with natural and processed steel slag aggregates. 
Hydrated lime is primarily used as an anti-stripping agent to inhibit moisture damage. Gradation of natural aggregates, processed steel slag aggregates, stone dust and hydrated lime along with their respective concentration in all in one aggregate blend, adopted for preparation of bituminous concrete $(\mathrm{BC}) \mathrm{mix}$ is given in Table 4.

\section{Table 4: Proportioning of Aggregates}

\begin{tabular}{|c|c|c|c|c|c|c|c|c|c|}
\hline \multirow{3}{*}{$\begin{array}{l}\text { Sieve } \\
\text { Size } \\
\text { in } \\
\mathrm{mm}\end{array}$} & \multicolumn{6}{|c|}{$\begin{array}{l}\text { Individual Gradation } \\
\text { (Percentage Passing) }\end{array}$} & \multicolumn{2}{|c|}{ Designed Blend } & \multirow{3}{*}{$\begin{array}{l}\text { MoRTH } \\
\text { Specified } \\
\text { Limits }\end{array}$} \\
\hline & $\begin{array}{c}\text { Natural } \\
\text { Aggregate } \\
0-10 \mathrm{~mm} \\
\text { (A) }\end{array}$ & \begin{tabular}{|c|} 
Natural \\
Aggregate \\
$10-20 \mathrm{~mm}$ \\
(B)
\end{tabular} & $\begin{array}{l}\text { Stone } \\
\text { Dust } \\
\text { (C) }\end{array}$ & $\begin{array}{l}\text { Hydrated } \\
\text { Lime } \\
\text { (D) }\end{array}$ & \begin{tabular}{|c|} 
Steel Slag \\
Aggregate \\
$0-10 \mathrm{~mm}$ \\
(E)
\end{tabular} & $\begin{array}{l}\text { Steel Slag } \\
\text { Aggregate } \\
10-20 \mathrm{~mm} \\
\text { (F) }\end{array}$ & $\begin{array}{l}\text { Natural } \\
\text { Aggregate } \\
\text { A:B:C:D } \\
\text { 20:50:28:2 }\end{array}$ & $\begin{array}{c}\text { Steel Slag } \\
\text { E:F:C:D } \\
\text { 10:60:28:2 }\end{array}$ & \\
\hline & 0.2 & 0.5 & 0.28 & 0.02 & 0.1 & 0.6 & 1 & 1 & \\
\hline 26.5 & 100 & 100 & 100 & 100 & 100 & 100 & 100 & 100 & 100 \\
\hline 19 & 100 & 100 & 100 & 100 & 100 & 100 & 100 & 100 & $79-100$ \\
\hline 13.2 & 100 & 42.13 & 100 & 100 & 100 & 60.90 & 71.07 & 76.54 & $59-79$ \\
\hline 9.5 & 85.60 & 32.16 & 100 & 100 & 88.97 & 40.77 & 63.20 & 63.36 & $52-72$ \\
\hline 4.75 & 62.43 & 10.13 & 99.83 & 100 & 78.57 & 2.30 & 47.50 & 39.19 & $35-55$ \\
\hline 2.36 & 19.23 & 3.46 & 92.47 & 100 & 25.17 & 0.00 & 33.47 & 30.41 & $28-44$ \\
\hline 1.18 & 10.87 & 0.00 & 73.50 & 100 & 4.57 & 0.00 & 24.75 & 23.04 & $20-34$ \\
\hline 0.6 & 4.10 & 0.00 & 51.20 & 100 & 0.00 & 0.00 & 17.16 & 16.34 & $15-27$ \\
\hline 0.3 & 0.00 & 0.00 & 41.40 & 1.41 & 0.00 & 0.00 & 11.62 & 11.62 & $10-20 "$ \\
\hline 0.15 & 0.00 & 0.00 & 28.70 & 8.63 & 0.00 & 0.00 & 8.21 & 8.21 & 5-13" \\
\hline 0.075 & 0.00 & 0.00 & 8.33 & 92.57 & 0.00 & 0.00 & 4.18 & 4.18 & $2-8^{\prime}$ \\
\hline
\end{tabular}

For both the mixes the grading distribution was optimized with reference to designed grading envelop of MoRTH specification. An aggregate gradation curve along with reference grading envelopes for bituminous concrete wearing course is shown in Figure 1.

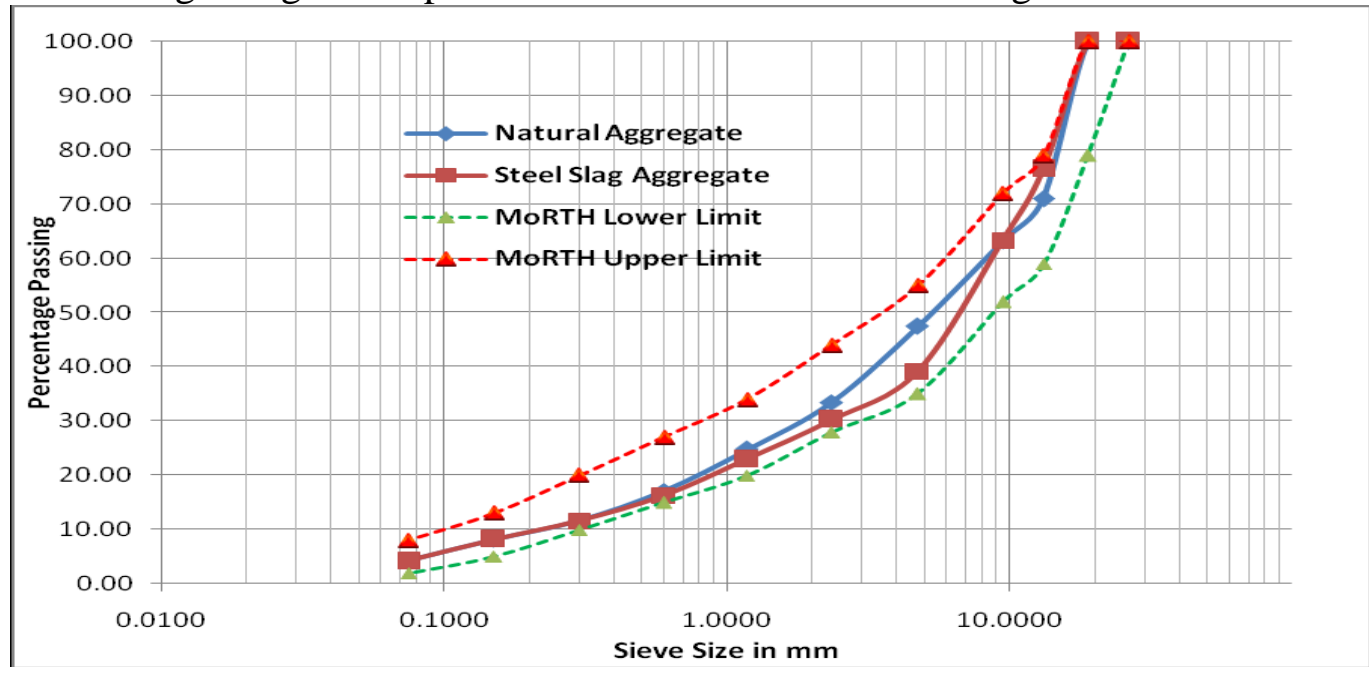

Figure 1: Gradation Curves of Bituminous Concrete Wearing Course 
Optimum bitumen content of steel slag modified and unmodified bituminous mixes were determined through Marshall Procedure as stipulated in ASTM D 1559. It is known that the optimum bitumen content is sensitive to aggregate type as well as gradation. The optimum bitumen content was determined based on maximum stability, maximum density, and $4 \%$ air voids as recommended in MoRTH specification.

\section{Performance Test Program}

The performance of the mixes optimized in the mix design was studied with respect to the basic mechanical properties of bituminous mixes and in relation to the principal causes of pavement failure. Both mixes were evaluated for indirect tensile strength, resilient modulus, resistance to permanent deformation, fatigue resistance and moisture damage.

\section{Indirect Tensile Strength}

Since fatigue failures are the result of cyclic tensile strains or stresses it was postulated by numerous researchers that tensile stiffness would correlate best with fatigue. Indirect tensile strength test is used to assess the tensile strength of modified and unmodified bituminous mixes. The test was carried out according to ASTM 4867M-04 test method by loading a Marshall specimen with compressive load acting parallel to and along the vertical diametric-loading plane. The tensile strength is calculated as follows:

$$
\mathrm{S}_{\mathrm{t}}=\frac{2 \mathrm{P}}{\pi \mathrm{tD}}
$$

Where $\mathrm{St}=$ tensile strength, $\mathrm{P}=$ maximum load, $\mathrm{t}=$ specimen height immediately before test, $\mathrm{D}=$ specimen diameter.

The tensile strength ratio of moisture conditioned and dry subset was also calculated to find out the moisture susceptibility of modified and unmodified mixes. Following formula was used to find out the tensile strength ratio of unmodified and modified bituminous mixes

$$
\operatorname{TSR}=\left(\frac{s_{\mathrm{tm}}}{s_{\mathrm{td}}}\right) * 100
$$

Where TSR = tensile strength ratio, $\mathrm{S}_{\mathrm{tm}}=$ average conditioned tensile strength of the moisture conditioned subset, $\mathrm{S}_{\mathrm{td}}=$ average tensile strength of the dry subset.

\section{Resilient Modulus}

The resilient modulus is an important parameter to determine the performance of pavement and to analyze pavement response to traffic loading. Moreover the resilient modulus can be considered as a synthetic indicator of the structural properties of the mixes (Hamzah O. M., et al, 2008; Pasetto M. et al, 2011). A non destructive test protocol was adopted according to ASTM D 4123-82. The test was conducted at four different test temperatures: $25^{\circ} \mathrm{C}, 30^{\circ} \mathrm{C}, 35^{\circ} \mathrm{C}$ and $40{ }^{\circ} \mathrm{C}$ for modified and unmodified mixes. The specimens were conditioned at the selected test temperature for 4 hours prior to testing. Repeated haversine load with a pulse width of 0.1 second and a pulse repetition period of 
3 seconds was used in all resilient modulus testing in order to avoid impact loading to specimens. The total resilient modulus (Ert) is defined as:

$$
E r t=\frac{P\left(\mathrm{v}_{\mathrm{RT}}+0.27\right)}{t * \Delta H t}
$$

Where Ert $=$ Total resilient modulus of elasticity $(\mathrm{MPa})$,

$\mathrm{P}=$ Repeated load $(\mathrm{N})$,

$v_{\mathrm{RT}}=$ Total resilient Poisson's ratio (a value of normally 0.35 used),

$\mathrm{t}=$ the thickness of specimen $(\mathrm{mm})$,

$\Delta \mathrm{Ht}=$ total recoverable horizontal deformation $(\mathrm{mm})$.

\section{Rutting Resistance}

Rutting is a longitudinal surface depression in the wheel paths. Rutting displaces the bituminous mixture in the wheel path and created channels. Rut resistance of unmodified and modified mixes were investigated through Wheel Tracking Test. Test was carried out as per AASHTO specification T-324 on bituminous concrete slab of $300 \times 300 \times 50 \mathrm{~mm}$ size. Test samples were prepared at optimum binder content for unmodified and steel slag modified bituminous mixes. Bi-directional loading is applied with the help of a steel wheel with a solid rubber tire subjected on a total load of $31 \mathrm{~kg}$ and producing mean normal pressure of $5.6 \mathrm{~kg} / \mathrm{cm}^{2}$. Loading was applied at the rate of 42 passes per minute along the length of the slab at $40{ }^{\circ} \mathrm{C}$ test temperature. Two specimens were tested for each mix and average rut depth after 10000 cycles (20000 passes) were calculated.

\section{Resistance to Permanent Deformation}

The resistance to permanent deformation has been investigated by static creep test. In the static creep test, a constant axial load is applied to the test specimens throughout the duration of the test. All specimens were subjected to a seating load of $78.5 \mathrm{~N}$ for ten minutes before being loaded with a constant axial load of $785.4 \mathrm{~N}$ for 60 minute duration. Strain recovery was noted for all specimens for 60 minute duration after the removal of the axial load. The static creep test was performed on universal testing machine. Test results are presented in Figure 4. Various other creep related parameters which clearly define the creep nature of the binder such as total deformation, permanent deformation and elastic recovery, are also calculated and presented in Table-7 for unmodified and steel slag modified mixes respectively.

\section{RESULTS AND DISCUSSION}

\section{Material Characterization and Mix Design}

Test results in table 2 shows that EAF steel slag aggregates found to meet out all important physical-mechanical characteristics of aggregates laid down in MoRTH specification for Road and Bridge Work, 2001 for preparation of bituminous concrete 
mixes. Steel slag aggregates found to offer higher resistance to abrasion and impact loading compare to natural aggregates. The $\mathrm{SiO}_{2} / \mathrm{CaO}$ ratio characterizes the steel slag aggregate as substantially alkaline aggregate, and ensures improved affinity with the weakly acid bitumen (Pasetto $M$ et al, 2011). EAF steel slag aggregates found to satisfy volumetric stability criteria while subjected on soundness test to simulate harsh weather conditions. Neither the natural nor steel aggregates exhibit the poor affinity with bitumen, while tested for striping after 24 hour immersion in water at $25^{\circ} \mathrm{C}$.

For both the mixes the aggregate grading were optimized with reference to the design grading envelop of MoRTH specification (Figure 1). The design grading curves are within the reference grading envelops (MoRTH Specification, 2001) for bituminous concrete wearing course of $19 \mathrm{~mm}$ nominal maximum size aggregate. For both the mixes three Marshall Specimens were prepared at varying binder content of $0.5 \%$, in the range of $4.5-6 \%$. The results of Marshall Mix design are summarized in Table 5.

Table 5: Volumetric Properties and Marshall Test Results

\begin{tabular}{|l|c|c|c|c|c|c|}
\hline \multicolumn{1}{|c|}{ Type of Mix } & $\begin{array}{c}\text { Air } \\
\text { voids } \\
(\%)\end{array}$ & $\begin{array}{c}\text { Optimum } \\
\text { Binder Content } \\
(\%)\end{array}$ & $\begin{array}{c}\text { Bulk } \\
\text { Density } \\
(\mathbf{g} / \mathbf{c c})\end{array}$ & $\begin{array}{c}\text { Marshall } \\
\text { Stability at } \\
\mathbf{6 0} \mathbf{C} \\
(\mathbf{k N})\end{array}$ & $\begin{array}{c}\text { Flow } \\
(\mathbf{m m})\end{array}$ & $\begin{array}{c}\text { VFB } \\
(\%)\end{array}$ \\
\hline $\begin{array}{l}\text { Unmodified Mix } \\
\text { (With Natural } \\
\text { aggregate) }\end{array}$ & 4.0 & 5.1 & 2.57 & 13.2 & 3.0 & 71.7 \\
\hline $\begin{array}{l}\text { Modified Mix } \\
\text { (With Processed Steel } \\
\text { Slag aggregate) }\end{array}$ & 4.0 & 5.0 & 2.91 & 14.85 & 3.1 & 77 \\
\hline
\end{tabular}

The optimal bitumen content of the mix resulted as being slightly lower for the steel slag modified mix may be due to higher specific gravity aggregates (Bagampadde U., et al, 1999). The mix with steel slag showed better Marshall results than the mix with $100 \%$ natural aggregates, with a net increment of Marshall stability of $12.5 \%$ and reduced flow. Steel slag modified mix meet out the requisites specified in MoRTH standard for bituminous concrete mixes thus acceptable for road construction in India.

\section{Indirect Tensile Strength}

The tensile strength, tensile strength ratio and retained Marshall stability of steel slag modified and unmodified mixes are reported in Table 6. Indirect tensile strength test revealed that steel slag modified bituminous mix showed improvement in tensile strength of the moisture conditioned and dry subset of bituminous mix by $7.5 \%$ and $3.5 \%$ respectively. Higher tensile strength is an indicator of improved resistance for fatigue 
cracking. Moisture susceptibility is typically a problem that can cause the bitumen binder to strip from the aggregate, leading to raveling and disintegration of the mixture. Resistance against moisture susceptibility was assessed by comparing the tensile strength ratio and retained Marshall Stability of modified and unmodified mix. Higher tensile strength ratio $(86.40 \%)$ and better retained Marshall Stability $(84 \%)$ were found in steel slag modified mixes. It indicates that modified mix having steel slag aggregate can resist moist weather conditions.

\section{Table 6: Results of Indirect Tensile Strength Test}

\begin{tabular}{|l|c|c|c|c|}
\hline \multicolumn{1}{|c|}{ Type of Mix } & $\begin{array}{c}\text { Average tensile } \\
\text { strength of } \\
\text { conditioned } \\
\text { subset, } \\
\text { (MPa) }\end{array}$ & $\begin{array}{c}\text { Average tensile } \\
\text { strength of the } \\
\text { dry subset, } \\
\mathbf{S}_{\mathbf{t d}} \text {, (MPa) }\end{array}$ & $\begin{array}{c}\text { TSR } \\
(\%)\end{array}$ & $\begin{array}{c}\text { Retained } \\
\text { Marshall } \\
\text { Stability, } \\
(\%)\end{array}$ \\
\hline $\begin{array}{l}\text { Unmodified Mix } \\
\text { (With Natural Aggregates) }\end{array}$ & 1.04 & 1.26 & 83.00 & 74.00 \\
\hline $\begin{array}{l}\text { Modified Mix } \\
\text { (With Steel Slag Aggregate) }\end{array}$ & 1.12 & 1.30 & 86.40 & 84.00 \\
\hline
\end{tabular}

\section{Resilient Modulus}

Indian specifications don't specify minimum threshold of resilient modulus for the acceptance of the mixtures, therefore the results can be considered useful only for a performance analysis to compare both the mixtures considered. It can be seen that from figure 2 that the bituminous mixes with steel slag showed better mechanical properties, with values of resilient modulus that were always higher than those of the mixture with natural aggregate, varying from 26 to $33 \%$ with respect to the temperature.

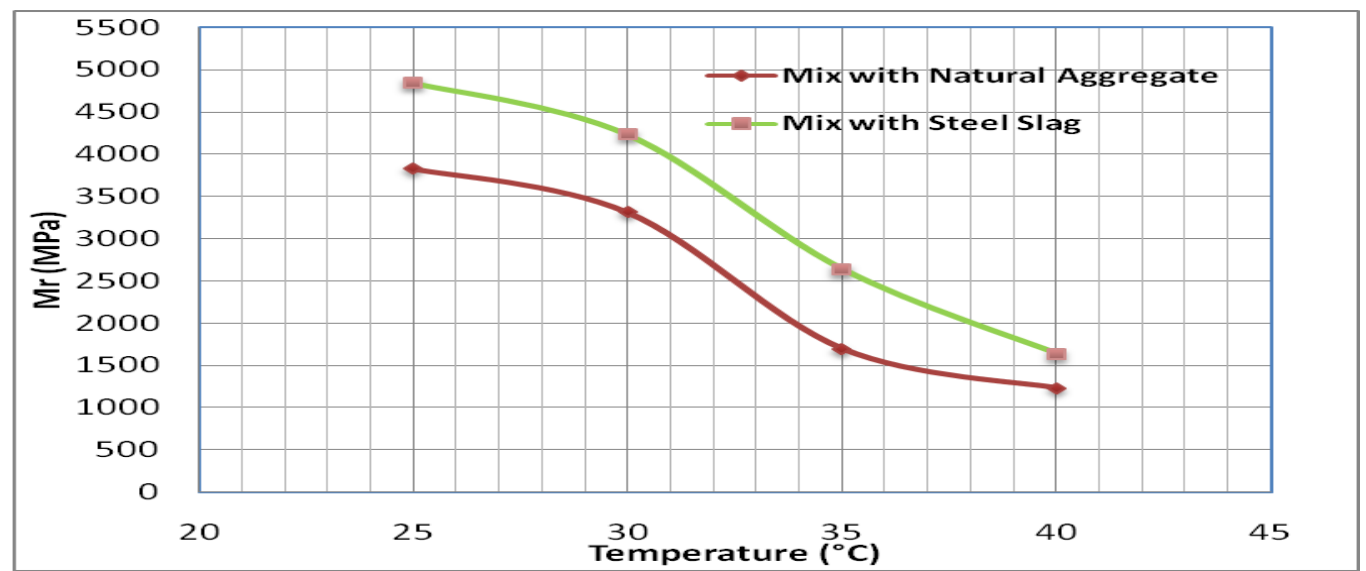

Figure 2: Resilient Modulus of Bituminous Mix with Steel Slag and Natural Aggregate 


\section{Rutting Resistance}

Figure 3 shows the results for the rutting potential of bituminous concrete with steel slag and natural aggregates. Average rut depths after 10000 cycles were found to be $4.08 \mathrm{~mm}$ and $3.11 \mathrm{~mm}$ in unmodified and steel slag modified bitumen mixes respectively. The results showed that the final rut achieved in slab made with steel slag aggregate as compared to that made with natural aggregate is about $23.77 \%$ less. The reduced rutting in steel slag mixture can be attributed to higher specific gravity of steel slag aggregates and better interlocking that steel slag interlocks well within the mixture, which is undeniably essential for deformation resistance. Thus steel slag aggregates can replace the natural aggregates in high performance bituminous mixes on high volume traffic corridors due to its greater adhesion ability and rut resistance.

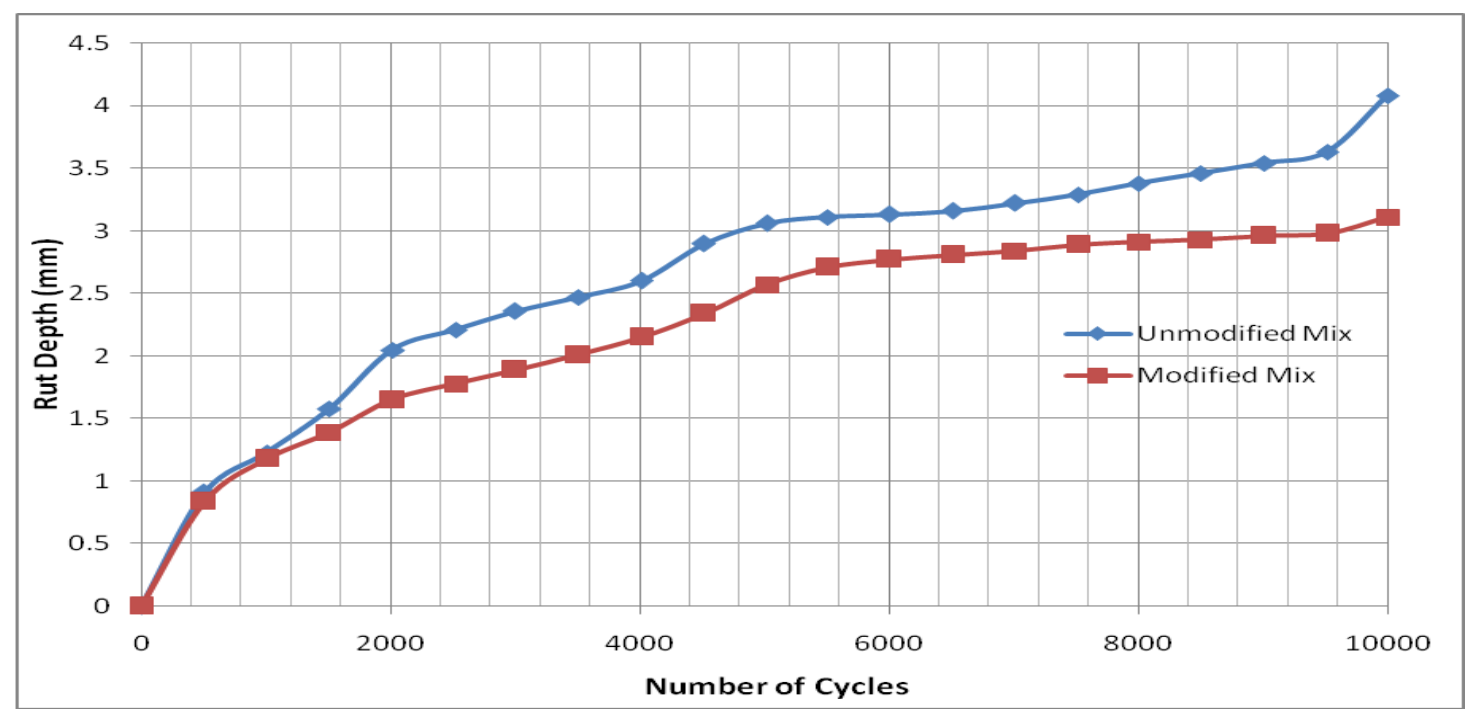

Figure 3 : Development of Rut vs Number of Cycles

\section{Resistance to Permanent Deformation}

Figure 4 reports the evolution of the creep curve and elastic recovery of the unmodified and steel slag modified bituminous mixes. The integration of steel slag in bituminous mixture clearly improves the resistance to permanent deformation. Permanent deformation for the steel slag mixture is $0.0537 \mathrm{~mm}$, while for the conventional mixture it is $0.289 \mathrm{~mm}$. Elastic recoveries (after the removal of the load) as indicated in Table 7, is $52.89 \%$ in case of steel slag modified mix while it is limited up to $23.54 \%$ in unmodified mix. The steel slag mix has good interlocking and adhesion, thus the modified mix can resist greater deformation and can last longer when compared to conventional mixture. 


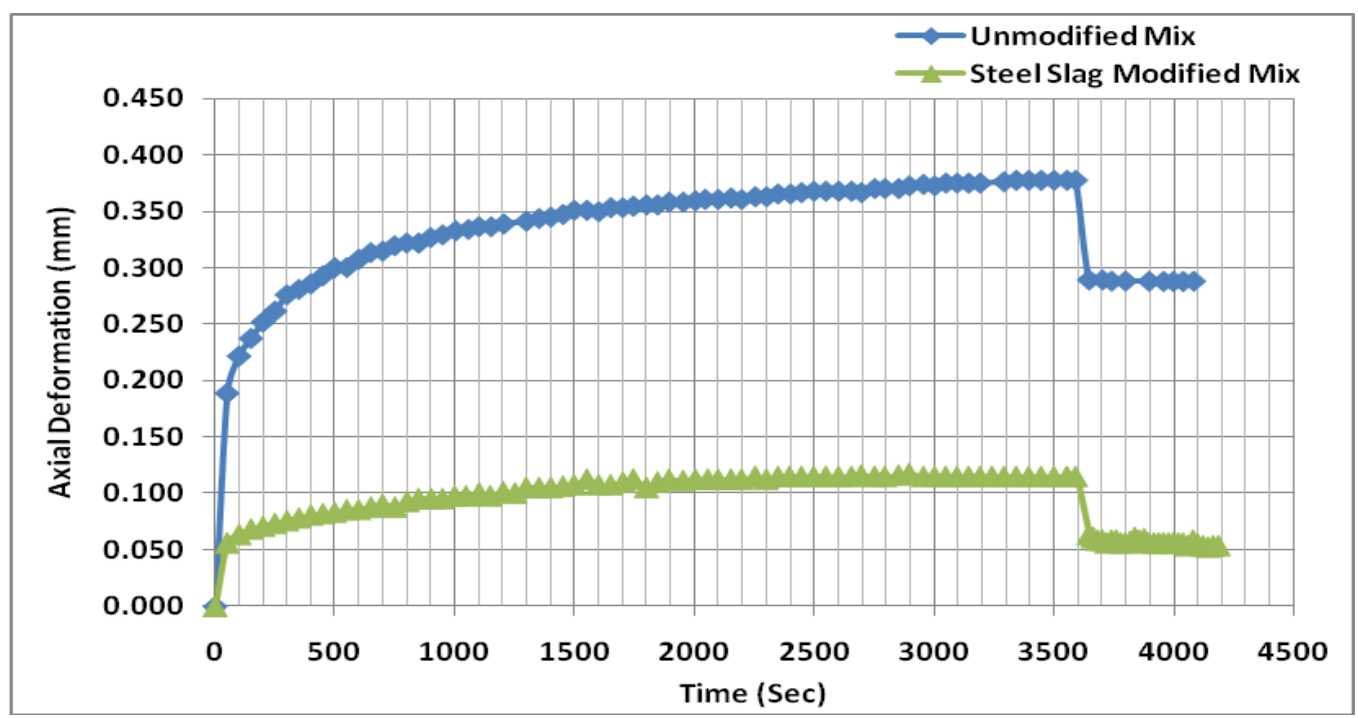

Figure 4: Axial Deformation Vs. Time

Table 7: Static Creep Test Results

\begin{tabular}{|c|c|c|c|c|c|c|}
\hline \multirow{2}{*}{$\begin{array}{c}\text { Temp. } \\
\left({ }^{0} \mathrm{C}\right)\end{array}$} & \multicolumn{2}{|c|}{$\begin{array}{l}\text { Total Deformation } \\
(\mathbf{m m})\end{array}$} & \multicolumn{2}{|c|}{$\begin{array}{l}\text { Permanent } \\
\text { Deformation }(\mathbf{m m})\end{array}$} & \multicolumn{2}{|c|}{ Elastic Recovery (\%) } \\
\hline & $\begin{array}{l}\text { Unmodified } \\
\text { Mix }\end{array}$ & $\begin{array}{l}\text { Modified } \\
\text { Mix }\end{array}$ & $\begin{array}{l}\text { Unmodified } \\
\text { Mix }\end{array}$ & $\begin{array}{l}\text { Modified } \\
\text { Mix }\end{array}$ & $\begin{array}{l}\text { Unmodified } \\
\text { Mix }\end{array}$ & $\begin{array}{l}\text { Modified } \\
\text { Mix }\end{array}$ \\
\hline 35 & 0.378 & 0.114 & 0.289 & 0.053 & 23.54 & 52.89 \\
\hline
\end{tabular}

\section{CONCLUSIONS}

The results obtained by laboratory testing of aggregates shows that EAF steel slag aggregate meets the Indian specifications for the use in bituminous mixes. Steel slag aggregates possess requisite physical and mechanical properties which are comparable with the natural aggregate produce from igneous rocks of silicate composition.

Mix design results are quite satisfactory for bituminous mix containing steel slag aggregates with good values of Marshall Stability and Retained Marshall Stability. Steel slag mix shows significant improvement in resistance to moisture damage and high resistance to permanent deformation. Improved resilient modulus at higher temperature and reduced susceptibility for rutting in steel slag modified mix pave the way for thinner bituminous layer as wearing course.

In conclusion the study found that the use of EAF steel slag in bituminous mixes may be a technically satisfactory option which can preserve rapidly depleting natural aggregate. Further the laboratory study reported in the paper is required to be complemented by field 
trial of steel slag aggregate bituminous mixes to establish beneficial effects for formulation of national specification.

\section{Acknowledgements:}

Authors are thankful to Dr. S. Gangopadhyay, Director, Central Road Research Institute (CRRI), New Delhi, for kind permission to undertake this study. A special thank is due to Mr. Nick Jones, Slag Business Development Manager, Harsco Metals Group Ltd. for invaluable suggestion and support during preparation of manuscript of this paper. Thanks are also due to Dr. Devesh Tiwari, Mr. Gagandeep Singh Scientist, CSIR- CRRI and Mr. Rajanikanth Reddy Senior Manager - Slag Co Products, Harsco India Pvt. Ltd. for their support in laboratory study and during the preparation of this paper.

\section{REFERENCES}

Bagampadde U., Wahaab A and Aiban A. S., (1999), "Optimization of Steel Slag Aggregates for Bituminous Mixes in Saudi Arabia" Journal of Materials in Civil Engineering, ASCE, Vol. 11 No. 1,PP. 30-35.

Central Pollution Control Board (CPCB) Report (2006-07), “Assessment of Utilization of Industrial Solid Wastes in Cement Manufacturing", Program Objective Series, Probes/103/2006-07.

Irem Z. Y. and Monica P., (2011), "Chemical, Mineralogical and Morphological Properties of Steel Slag", Journal Advances in Civil Engineering, Vol. No.2011 pp $1-13$.

Juan M. M., Milagros L., Juan A. P., and Javier J. G., (2005), "Ladle Furnace Slag in Construction" Journal of Materials in Civil Engineering, ASCE, Vol. 17 No. 5, PP. 513-518.

Hamzah O. M , and Teoh C. Yi (2008), "Effects of Temperature on Resilient Modulus of Dense Asphalt Mixtures Incorporating Steel Slag Subjected to Short Term Oven Aging” World Academy of Science, Engineering and Technology 46, PP. 221-225.

Hunt L. and Boyle G. E (2000), "Steel Slag in Hot Mix Asphalt Concrete", Final Report No. OR-RD-00-09, Oregon Department of Transportation, Research Group, 200 Hawthrone SE, Suite B-240, Salem.

Han Y. M., Jung H. Y. and Seong S. K., (2002), "A Fundamental study on the Steel Slag Aggregate for Concrete” Geosystem Eng., 5(2), pp 38-45. 
Mladen F., Andrea S. and Ruzica R., (2010) "Properties of Steel Slag Aggregate and Steel Slag Asphalt Concrete", Slovenian Congress on Roads and Traffic held at Portoroz PP. 1359-1366.

Ministry of Road Transport and Highway "Specification for Road and Bridge Work" Fourth Revision, 2001, Indian Road Congress, New-Delhi.

Pasetto M. and Baldo N. (2011), "Mix Design and Performance Analysis of Asphalt Concretes with Electric Arc Furnace Slag", Construction and Building Materials, Elsevier, Science Direct, Vol. No. 25 pp 3458 - 3468. 